\title{
Period prior to interference of barnyardgrass is modified due to the spraying of cyhalofop-butyl alone or associated with penoxsulam in paddy rice crop
}

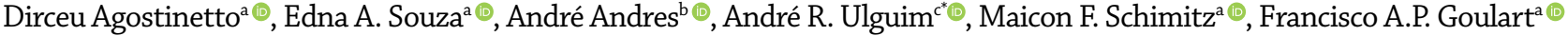 \\ a Universidade Federal de Pelotas, Capão do Leão, RS, Brazil. ' Embrapa Clima Temperado, Estação Experimental Terras Baixas, Capão do Leão, RS, \\ Brazil. c Universidade Federal de Santa Maria, Santa Maria, RS, Brazil.
}

Abstract: Background: Weed competition is one of the main constraints to rice yield.

Objective: Determine the period prior to interference (PPI) of barnyardgrass (Echinochloa spp.) on the irrigated rice crop as a function of the application of the herbicide cyhalofop-butyl alone and associated with penoxsulam.

Methods: A field experiment was carried out in a randomized block design, with four replications. The treatments were arranged in a $2 \times 7$ factorial scheme, with factor A consisting of the herbicides cyhalofop-butyl and the mixture penoxsulam + cyhalofop-butyl, while factor B consisted of seven coexistence periods: $0,7,14,21,28,35$, and 120 days after rice emergence (DAE). The herbicides were applied in each of these periods. The analyzed variables were crop height and shoot dry mass of the rice and barnyardgrass, number of grains per panicle, thousand-grain weight, and yield.

Results: The presence of barnyardgrass competing for environmental resources negatively affected the analyzed variables and rice yield for all periods with a coexistence longer than 28 DAE. Barnyardgrass competition during the entire rice cycle (120 DAE) reduced the shoot dry mass of the crop.

Conclusions: The PPI termination was determined at 14 DAE for the mixture cyhalofop-butyl + penoxsulam and 29 DAE for cyhalofop-butyl alone.

Keywords: Oryza sativa; Echinochloa spp.; Chemical control; Mode of action of herbicides

Journal Information:

ISSN - 2675-9462

Website: http://awsjournal.org

Journal of the Brazilian Weed

Science Society

How to cite: Agostinetto D, Souza EA, Andres A, Ulguim AR, Schimitz MF, Goulart FAP. Period prior to interference of barnyardgrass is modified due to the spraying of cyhalofop-butyl alone or associated with penoxsulam in the rice crop. Adv Weed Sci. 2021;39:e021225214.

https://doi.org/10.51694/AdvWeedSci/2021;39:00001

Approved by:

Editor in Chief: Aldo Merotto Junior

Conflict of Interest: The authors declare that there is no conflict of interest regarding the publication of this manuscript.

Received: June 14, 2019

Approved: August 10, 2020

* Corresponding author: <andre.ulguim@ufsm.br>

\section{(c) (4)}

This is an open-access article distributed under the terms of the

Creative Commons Attribution License, which permits unrestricted use, distribution, and reproduction in any medium, provided that the original author and source are credited.

Copyright: 2021

\section{Introduction}

Weed occurrence is one of the main obstacles to the expression of the production potential of crops. Competition for one or more limiting environmental resources $\left(\mathrm{CO}_{2}\right.$, water, light, and nutrients) can generate irreversible losses to crops, and there may be no recovery of their development even after the removal of the stress caused by weeds or inclusion of limiting resources to the environment (Karimmojeni et al., 2014).

The average losses in rice yield due to the coexistence with weeds are estimated between 40 and $60 \%$, reaching up to $96 \%$ in cases of lack of control (Chauhan and Johnson, 2011). The degree of weed interference is determined according to the species, density, location, availability of resources, and emergence period relative to the crop (Datta et al., 2017). However, the losses caused to the crop can be altered as the period in which the weed community coexists with the crop changes. Crop and weeds can live together at the beginning of development for a certain period without causing quantitative or qualitative losses to the crop (Silva et al., 2014). This stage, called the period prior to interference (PPI), corresponds to the period after emergence or sowing in which the crop can coexist with the weed community without negatively affecting yield or other characteristics (Silva et al., 2014). However, control measures must be adopted at the end of this period so that crop yield is not compromised (Silva and Durigan, 2006).

Studies of competition periods conducted with the rice crop have shown that PPI duration can vary from 7 to 26 DAE (Silva and Durigan, 2006; Zhang et al., 2003). Variations in topography, climate, crop genetics, and management practices affect weed composition, weed density, and emergence time relative to the crop and, consequently, affect PPI (Korres and Norsworthy, 2015). This variability needs to be understood for the better use of the integrated weed management of each environment. Among the weed species in rice fields, barnyardgrass (Echinochloa spp.) stands out relative to the others due to its highly competitive ability compared to the crop (Agostinetto et al., 2008). The importance of this weed is due to its morphophysiological similarities with rice plants, denoting the potential for yield losses because of competition, as well as high infestation levels and a wide distribution in commercial crops (Andres et al., 2007). 
Chemical control in the integrated management program represents the main tool for weed control in irrigated rice areas (Agostinetto et al., 2011). The main herbicides used to control barnyardgrass in the post-emergence of nonClearfield $^{\circ}$ rice are cyhalofop-butyl, an acetyl-coenzyme A carboxylase (ACCase) inhibitor, and penoxsulam, an acetolactate synthase (ALS) inhibitor, both of which are considered efficient and selective (Sosbai, 2014). On the other hand, the mixture of cyhalofop-butyl and penoxsulam can be used to broaden the spectrum of control, as these herbicides also present an effect on Cyperaceae species and eudicots due to the presence of penoxsulam.

Studies of interference periods are usually carried out by mechanically removing weeds. However, the information generated from these studies has been used in commercial cultivations for decision-making regarding the chemical management of weeds. Thus, the hypothesis is that weed control using herbicides increases PPI compared to mechanical removal, leading to an error in the interpretation of results in the literature and yield loss by farmers. In addition, the use of different herbicides or their association can affect this period in which control should be carried out without crop losses. In this context, this study aimed to determine the period prior to interference (PPI) of the barnyardgrass in the irrigated rice crop due to the application of cyhalofop-butyl and the commercial mixture of cyhalofopbutyl + penoxsulam in different periods after emergence.

\section{Material and Methods}

The experiment was carried out in the field in the 2015/16 growing season at Empresa Brasileira de Pesquisa Agropecuária (Embrapa) Temperate Agriculture at the Lowland Areas station, with soil classified as a solodic Eutrophic Hydromorphic Planosol. The experimental design was a randomized block design with four replications and experimental units consisting of $12.5 \mathrm{~m}^{2}$ plots $(2.5 \times 5.0 \mathrm{~m})$.

The treatments were arranged in a $2 \times 7$ factorial scheme. Factor A consisted of the herbicide management, that is, cyhalofop-butyl (315 g a.i. ha-1) plus vegetable oil (1.5 L ha-1) and the mixture cyhalofop-butyl + penoxsulam $(385.22+$ $54 \mathrm{~g}$ a.i. ha ${ }^{-1}$ ) plus vegetable oil $\left(1.5 \mathrm{~L} \mathrm{ha}^{-1}\right)$, while factor $\mathrm{B}$ consisted of the coexistence periods $0,7,14,21,28,35$, and 120 days after rice emergence (DAE). In these periods, the rice was maintained in the presence of barnyardgrass until a determined time, and from that moment on, the plots were maintained clean until the end of the cycle through reapplication of the aforementioned herbicides. Control failures and eudicot weeds from the treatment with cyhalofop-butyl were removed manually from the plots. Spraying was carried out using a $\mathrm{CO}_{2}$-pressurized knapsack sprayer equipped with 110.015 tips and calibrated for a flow of $120 \mathrm{~L} \mathrm{ha}^{-1}$.

Weed control prior to treatments was carried out by desiccating the area the day before sowing with glyphosate at a dose of $720 \mathrm{~g}$ a.e. $\mathrm{ha}^{-1}$. The rice crop was grown under a conventional cultivation system. Sowing density corresponded to $110 \mathrm{~kg}$ seeds ha-1 of the cultivar BRS Pampa. Fertilization was carried out according to soil analysis, which required $442 \mathrm{~kg} \mathrm{ha}^{-1}$ of fertilizer $05-25-25$. The fertilizer and seeds were distributed using a seed drill with discs spaced at $0.17 \mathrm{~cm}$. Nitrogen fertilization was carried out at the V4 and V8 stages using 200 and $50 \mathrm{~kg} \mathrm{ha}^{-1}$ of chlorinated urea, respectively. The other management practices followed the technical recommendations of the irrigated rice crop (Sosbai, 2014).

The crop emerged 18 days after sowing when the first period (0 DAE) was established. Crop height $(\mathrm{CH})$ and shoot dry mass (SDM) of the crop and barnyardgrass were evaluated for each period before herbicide applications. Ten plants were randomly measured in each plot to determine $\mathrm{CH}$ by taking the length from the ground level to the plant apex, with the leaf blade distended. The SDM was determined by collecting crop or barnyardgrass plants from an area of $0.25 \mathrm{~m}^{2}$ in each plot and, subsequently, the samples were dried in a forced-air circulation oven at $60{ }^{\circ} \mathrm{C}$ for 72 hours and the final mass was measured on a precision scale.

Ten panicles were collected at harvest from the useful area of each experimental unit to determine the number of full grains per panicle (NGP). Grain yield was estimated by harvesting the useful area $\left(4.08 \mathrm{~m}^{2}\right)$ of each plot, weighing the grains, and correcting the mass to $13 \%$ moisture, with values expressed in $\mathrm{kg} \mathrm{ha}^{-1}$. The thousand-grain weight (TGW) was estimated by manually counting eight samples of 100 grains, with the values corrected for 1000 grains and expressed in grams.

The data were analyzed for normality (ShapiroWilk test) and subsequently subjected to analysis of variance $(\mathrm{p} \leq 0.05)$. In the case of significance, the herbicide effects were analyzed by the Duncan test $(p \leq 0.05)$ and the effects of collection times were analyzed by the t-test $(p \leq 0.05)$. The thee-parameter logistic sigmoid regression equation was used to determine the period of coexistence (PPI) (Velini, 1992):

$$
y=a /\left[1+(x / x 0)^{b}\right]
$$

where $y$ is the grain yield, $a$ is the maximum minus the minimum value estimated by the model, $x$ is the number of days after crop emergence, $\chi 0$ is the number of days on which $50 \%$ of the reduction occurs, and $b$ is the slope of the curve.

The period prior to interference (PPI) was estimated by deducting the maximum rice production estimated by the model, in which $5 \%$ corresponding to the cost of adopting chemical weed control.

\section{Results and Discussion}

The analysis of variance showed a simple effect of the coexistence periods on the variables SDM (Table 1), $\mathrm{CH}$, NGP, and TGW (Table 2) for rice. Also, a simple effect of the coexistence periods was observed on the variable SDM for barnyardgrass (Table 1 ). The variable yield showed an 
interaction between the herbicide treatments and periods of coexistence with barnyardgrass (Table 3 ).

A gradual increase in SDM of barnyardgrass was observed as the days after crop emergence (DAE) increased, with the highest accumulation at 120 DAE (213.34 $\left.\mathrm{g} \mathrm{m}^{-2}\right)$. The SDM of rice showed no difference between periods 0 , $7,14,21$, and 120 DAE (Table 1). Moreover, SDM of rice decreased 66.8 times from 35 to 120 DAE, while that of barnyardgrass increased 10.4 times during the same period. These results show that the coexistence of barnyardgrass throughout the rice crop cycle has dramatically reduced the SDM of the crop.

The reduction in SDM of rice has also been observed in other studies, mainly due to the increase in the population of different barnyardgrass biotypes (Tironi et al., 2009). Different rice cultivars in competition with different barnyardgrass populations showed a reduction in SDM under all studied associations (Agostinetto et al., 2008). According to the authors, the higher the production of the competitor, the higher the crop losses. These results show suppression of crop development as SDM of barnyardgrass increases, especially when no control method is used, reducing or paralyzing SDM accumulation.

All coexistence periods showed a difference for the variable $\mathrm{CH}$, with an increase observed throughout the cycle, except for $120 \mathrm{DAE}$, when $\mathrm{CH}$ showed a lower value at 35 DAE, which was due to the competition with barnyardgrass throughout the cycle (Table 2). Barnyardgrass has a $C 4$ photosynthetic mechanism and, therefore, a higher growth rate and efficiency in the use of environmental resources than $\mathrm{C} 3$ plants such as rice, also reaching a higher competitive advantage regardless of the interference level (Chauhan and Johnson, 2010; Sage, 2000). However, CH may not change due to weed interference periods, as it is a growth variable influenced by environmental conditions and weed infestation density.

In some cases, the negative effect of the competition period can be expressed in the yield components, with a penalty on crop yield. Therefore, the coexistence of rice and barnyardgrass up to 35 DAE did not change NGP. However, this variable was reduced by $60 \%$ when crop and weed coexisted together until 120 DAE (Table 2). Similar results also showed a $75 \%$ reduction in NGP when rice coexisted with barnyardgrass throughout the crop cycle (Chauhan and Johnson, 2011). Similar to NGP, TGW showed no difference until 35 DAE, differing only at 120 DAE (Table 2). Similar results were found for rice, whose grain mass was reduced by approximately $5 \%$ when in competition with barnyardgrass (Balbinot Junior et al., 2003).

These results can be explained by the degree of competition between weeds and crop, which is higher when the interference period and duration are prolonged, being established from the first days of coexistence under a high infestation in the area (Furtado et al., 2012). Thus, crop and weeds can coexist without losses to the crop of interest at the beginning of the cycle. However, resources become scarce to sustain full development as the crop cycle advances, leading to a reduction in the accumulation of photoassimilates, changing the partition of resources, and, consequently, reducing the quantity and mass of grains produced per plant (Silva et al., 2014).

Rice yield was reduced with an increase in the coexistence period for both cyhalofop-butyl and cyhalofop-butyl + penoxsulam, with the lowest value observed at 120 DAE (Table 3). An average reduction of $99.6 \%$ in yield was observed when the crop was maintained in the competition until harvest (120 DAE) compared to the competition-free plots for the two treatments with herbicides. Barnyardgrass has a high capacity to compete for environmental resources and phenotypic plasticity, which allows changing its morphology to increase the acquisition of limited resources, thus expressing its higher competitive ability (Chauhan and Johnson, 2011; Gibson and Fischer, 2001), a fact that would justify this sharp decline in yield. Similarly, Chauhan and Johnson (2010) observed that competition with barnyardgrass reduced rice yield by $86 \%$.

Table 1 - Shoot dry mass (SDM) of rice and barnyardgrass plants as a function of weed coexistence periods and days after crop emergence (DAE)

\begin{tabular}{l|c|c}
\multirow{2}{*}{ Period (DAE) } & \multicolumn{2}{|c}{ SDM $\left(\mathbf{g ~ m}^{-2}\right)$} \\
\cline { 2 - 3 } & Rice & Barnyardgrass \\
\hline 0 & $0.15 \mathrm{c}$ & $0.40 \mathrm{~d}$ \\
\hline 7 & $0.47 \mathrm{c}$ & $2.61 \mathrm{~d}$ \\
14 & $0.77 \mathrm{c}$ & $4.70 \mathrm{~d}$ \\
\hline 21 & $1.23 \mathrm{c}$ & $7.70 \mathrm{~cd}$ \\
\hline 28 & $2.95 \mathrm{~b}$ & $16.36 \mathrm{bc}$ \\
\hline 35 & $4.68 \mathrm{a}$ & $20.46 \mathrm{~b}$ \\
\hline 120 & $0.07 \mathrm{c}$ & $213.34 \mathrm{~A}$ \\
\hline CV (\%) & 113.9 & 24.6 \\
\hline
\end{tabular}

(1) Days after emergence. Means followed by different letters in the column differ from each other by Duncan's test ( $p \leq 0.05$ ).

Table 2 - Height (cm), number of full grains per panicle (NGP), and thousand-grain weight (g) (TGW) of the rice crop as a function of the coexistence periods with barnyardgrass in days after crop emergence (DAE)

\begin{tabular}{|l|c|c|c|}
\hline Period (DAE) ${ }^{(1)}$ & $\begin{array}{c}\text { Height } \\
(\mathbf{c m})(\mathrm{CH})\end{array}$ & $\begin{array}{c}\text { Number of grains } \\
\text { per panicle (NGP) }\end{array}$ & $\begin{array}{c}\text { Thousand-grain } \\
\text { weight (TGW) }\end{array}$ \\
\hline 0 & $3.62 \mathrm{~g}$ & $147.30 \mathrm{a}$ & $27.96 \mathrm{a}$ \\
\hline 7 & $8.91 \mathrm{f}$ & $145.13 \mathrm{a}$ & $27.91 \mathrm{a}$ \\
\hline 14 & $12.83 \mathrm{e}$ & $128.55 \mathrm{a}$ & $27.42 \mathrm{a}$ \\
\hline 21 & $15.63 \mathrm{~d}$ & $132.56 \mathrm{a}$ & $27.46 \mathrm{a}$ \\
\hline 28 & $27.53 \mathrm{~b}$ & $138.79 \mathrm{a}$ & $27.20 \mathrm{a}$ \\
\hline 35 & $42.53 \mathrm{a}$ & $136.69 \mathrm{a}$ & $27.94 \mathrm{a}$ \\
\hline 120 & $21.78 \mathrm{c}$ & $55.65 \mathrm{~b}$ & $7.00 \mathrm{~b}$ \\
\hline CV (\%) & 12.2 & 15.9 & 3.8 \\
\hline
\end{tabular}

(1) Days after emergence. Means followed by different letters in the column differ from each other by Duncan's test ( $p \leq 0.05$ ). 
The highest yield under cyhalofop-butyl application was achieved at $7 \mathrm{DAE}$, being similar to 14,21 , and 28 DAE, which did not differ from 0 DAE (Table 3). The treatment carried out with the mixture cyhalofop-butyl + penoxsulam ensured the highest yield until 21 DAE, with no differences between periods. A reduction in yield was observed from 28 DAE of coexistence between rice and barnyardgrass due to the extended time in which the crop remained with weeds.

The lowest yield of the treatment with cyhalofopbutyl at 0 DAE than 7 DAE may be due to the higher soil disturbance caused by the removal of plants established before the beginning of flood irrigation and, mainly, the difficulty of removing the weeds in the sowing row, which have been removed throughout the cycle according to their differentiation from the crop, leading to losses by competition. The comparison between the effects of herbicide treatments showed a difference in yield at 21 and $28 \mathrm{DAE}$, in which the mixture of cyhalofop-butyl and penoxsulam was superior at 21 DAE than the cyhalofop-butyl alone, but the highest yield at 28 DAE was observed in the treatment with cyhalofopbutyl alone (Table 3). Overall, the yield was higher when the mixture of herbicides was used (Table 3 ). The association of cyhalofop-butyl and penoxsulam presents higher speed and efficiency in the control of barnyardgrass than the application of cyhalofop-butyl alone (Bundt et al., 2015).

Although the ALS and ACCase inhibitors cause a slow evolution of symptoms until weeds die, the commercial mixture of cyhalofop-butyl and penoxsulam results in the faster and more efficient control of barnyardgrass their applications alone (Yadav et al., 2018). In addition to the stage of weeds and crop, as well as environmental conditions, the speed with which the herbicide paralyzes the growth of plants and causes their death is an important

\begin{tabular}{|c|c|c|}
\hline \multirow[b]{2}{*}{ Period (DAE) $)^{(1)}$} & \multicolumn{2}{|c|}{ Yield (kg ha-1) } \\
\hline & Cyhalofop-butyl & $\begin{array}{c}\text { Cyhalofop-butyl + } \\
\text { penoxsulam }\end{array}$ \\
\hline 0 & $6,110.5 b^{n s}$ & 7,318.4 a \\
\hline 7 & $7,364.4 a^{\text {ns }}$ & $8,050.8$ a \\
\hline 14 & $6,572.5 a^{n n s}$ & $7,722.0$ a \\
\hline 21 & $6,546.8 a^{*}$ & $7,605.0$ a \\
\hline 28 & $6,382.6 a b^{*}$ & 4,979.4 b \\
\hline 35 & $4,755.5 c^{n s}$ & 4,929.4 b \\
\hline 120 & $27.3 d^{\text {ns }}$ & $28.3 c$ \\
\hline CV (\%) & 10.0 & 8.8 \\
\hline
\end{tabular}

(1) Days after emergence. Means followed by different letters in the column differ from each other by Duncan's test ( $p \leq 0.05)$. * or ns compare each variable in the row, significantly differing or not by the t-test ( $p \leq 0.05)$. factor that must be taken into account to define the application date when weeds coexist with the crop.

The periods in which the crop coexisted with barnyardgrass allowed estimating when this weed emerges and coexists with the rice without yield losses (Figure 1). PPI was determined considering the value of $5 \%$ of the maximum yield estimated by the equation as being the cost of chemical control for the treatments cyhalofop-butyl + penoxsulam and cyhalofop-butyl. In this case, the PPI of the treatment with the mixture of herbicides was $14 \mathrm{DAE}$ of the rice crop and that of the treatment with cyhalofop-butyl alone was 29 DAE. Studies on the competition periods have shown similar results, with shorter PPI ranging from 7 to 12 DAE (Silva and Durigan, 2006; Zhang et al., 2003) and longer from 22 to $28 \mathrm{DAE}$ (Silva and Durigan, 2009). This variation is related to the species and population of weeds competing with rice, cultivar, site of study, and management.

The results showed a longer interval between the crop emergence and the application of the herbicide cyhalofop-butyl to control barnyardgrass. However, this interval was shorter for the treatment with the mixture cyhalofop-butyl + penoxsulam due to the possible phytotoxicity of penoxsulam to the crop, which resulted in a reduced yield from 28 DAE (Table 3 and Figure 1) and promoted a slope of the sigmoid logistic model (Figure 1). Moreover, the mixture with penoxsulam is favorable under the condition of the occurrence of eudicot species in the area due to the higher spectrum of control, a situation that was circumvented in the present study through the mechanical removal of weeds in the treatment with cyhalofop-butyl alone.

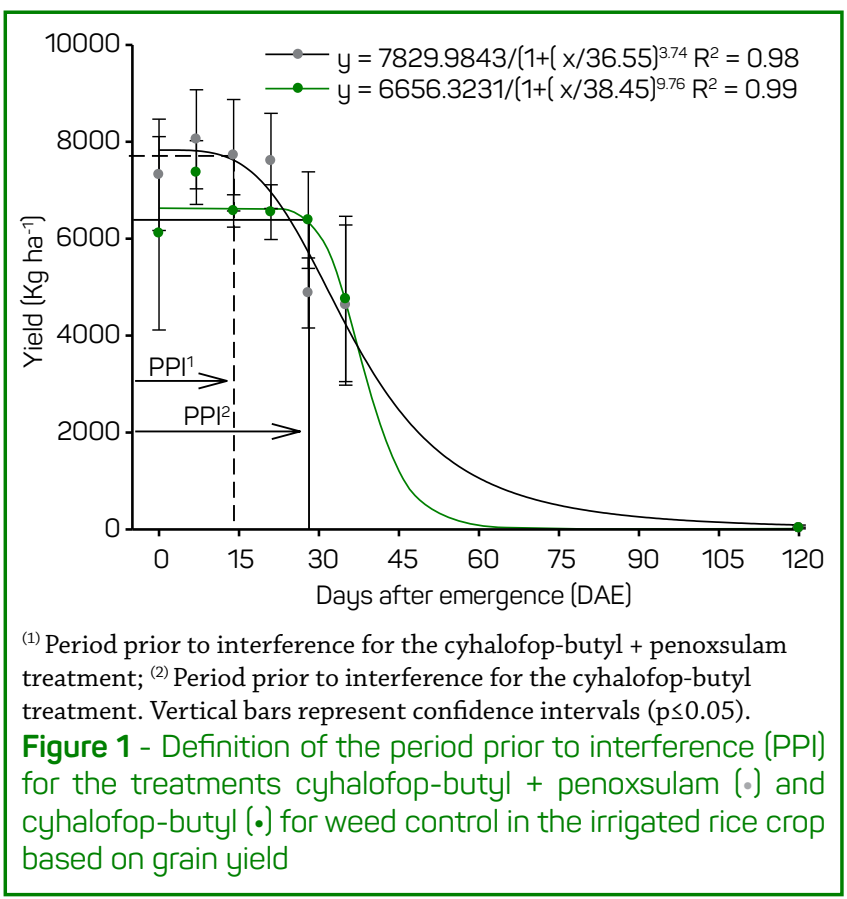




\section{Conclusions}

The presence of barnyardgrass competing for environmental resources negatively affects rice yield for all periods with coexistence for more than 28 DAE for cyhalofop-butyl alone and 21 DAE for cyhalofop-butyl + penoxsulam. In addition, weed control measures in the rice crop should be taken at the end of PPI, that is, 14 DAE when using the mixture cyhalofop-butyl + penoxsulam and $29 \mathrm{DAE}$ for cyhalofop-butyl alone.

\section{Author's contributions}

DA: Conceptualization, project administration, supervision, writing - review, and editing. EAS: Data curation, formal analysis, methodology, and writing
- original draft. AA: Conceptualization, project administration, supervision, writing - review, and editing. ARU: Formal analysis, validation, writing - review, and editing. MFS: Formal analysis and methodology. FAPG: Data curation, formal analysis, and methodology.

\section{Funding}

The authors thank the Coordination for the Improvement of Higher Education Personnel (Coordenação de Aperfeiçoamento de Pessoal de Nivel Superior - CAPES) - Financing Code 001. To the National Council for Scientific and Technological Development (Conselho Nacional de Desenvolvimento Científico e Tecnológico - CNPq) for the research productivity grant of Dr. Dirceu Agostinetto (308363/2018-3 CNPq).

\section{References}

Agostinetto D, Galon L, Moraes PV, Rigoli RP, Tironi SP, Panozzo LE. [Relative competitivity between flooded rice cultivars and Echinochloo spp]. Planta Daninha. 2008;26(4):757-66. Portuguese. Available from: https://doi.org/10.1590/S0100-83582008000400007

Agostinetto D, Dal Magro T, Vargas L, Noldin JA. [Cyperus difformis L. resistance to pyrazosulfuron-ethyl herbicide and option control]. Semina: Cienc Agrar. 2011;32(3):839-48. Portuguese. Available from: https://doi.org/10.5433/1679-0359.2011v32n3p839

Andres A, Concenço G, Melo PT, Schmidt M, Resende RG. [Detection of Echinochloo sp. resistance to quinclorac in rice fields in Southern Brazil]. Planta Daninha. 2007;25(1):221-6. Portuguese. Available from: https://doi.org/10.1590/S0100-83582007000100025

Balbinot AA Junior, Fleck NG, Menezes VG, Agostinetto D. [Competitiveness of flooded rice cultivars with a red rice simulating cultivar] Pesq Agropec Bras. 2003;38(1):53-9. Portuguese. Available from: https://doi.org/10.1590/S0100-204X2003000100007

Bundt AD, Mariot CH, Rubin RS. [Efficacy of the formulated mixture of cyhalofop+penoxsulam on controlling weeds in paddy rice]. In: Anais do Congresso Brasileiro de Arroz Irrigado, 11-14 ago 2015; Pelotas, Brazil. Pelotas: Sociedade Sul-Brasileira do Arroz irrigado; 2015. p. 176-9. Portuguese.

Chauhan BS, Johnson DE. Implications of narrow crop row spacing and delayed Echinochloo colono and Echinochloo crusgalli emergence for weed growth and crop yield loss in aerobic rice. Field Crops Res. 2010;117(23):177-82. Available from: https://doi.org/10.1016/j.fcr.2010.02.014

Chauhan BS, Johnson DE. Ecological studies on Echinochloo crusgalli and the implications for weed management in $\mathrm{di}$ rect-seeded rice. Crop Prot. 2011;30(11):1385-91. Available from: https://doi.org/10.1016/j.cropro.2011.07.013

Datta A, Ullah H, Tursun N, Pornprom T, Knezevic SZ, Chauhan BS. Managing weeds using crop competition in soybean [Glycine max (L.) Merr.]. Crop Prot 2017;95:60-8. Available from: https://doi.org/10.1016/j.cropro.2016.09.005

Furtado GF, Sousa JR, Sousa Junior JR, Lacerda RR, Souza AS. [Weed interference periods in sunflower]. Rev Verde. 2012;7(3):12-7. Portu- guese. Avaliable from: https://www.gvaa.com.br/revista/index.php/ RVADS/article/view/1324/1203

Gibson KD, Fischer AJ. Relative growth and photosynthetic response of water-seeded rice and Echinochloo oryzoides (Ard.) Fritsch to shade. Int J Pest Manag. 2001;47(4):305-9. Available from: https://doi.org/10.1080/09670870110052086

Karimmojeni H, Barjasteh A, Mousavi RS, Bazrafshan AH. Determination of the critical period of weed control in potato (Solanum tuberosum L.). New Zeal J Crop Hort. 2014;42(3):151-60. Available from: https://doi.org/10.1080/01140671.2013.875926

Korres NE, Norsworthy JK. Influence of a rye cover crop on the critical period for weed control in cotton. Weed Sci. 2015;63(1):346-52. Available from: https://doi.org/10.1614/WS-D-14-00075.1

Sage RF. $C_{3}$ versus $C_{4}$ photosynthesis in rice: ecophysiological perspectives. Studies Plant Sci. 2000;7:13-35. Available from: https://doi.org/10.1016/S0928-3420(00)80004-X

Silva C, Silva AF, Vale WG, Galon L, Petter FA, May A, et al. [Weed interference in the sweet sorghum crop]. Bragantia. 2014;73(4):438-45. Portuguese. Available from: https://doi.org/10.1590/1678-4499.0119

Silva MR, Durigan JC. [Interference periods of weeds in the upland rice - Caiapó variety]. Bragantia. 2009;68(2):373-9. Portuguese. Available from: https://doi.org/10.1590/S0006-87052009000200011

SilvaMR,DuriganJC. [Periodsofweedinterferenceintheuplandrice:I-Variety IAC 202]. Planta Daninha. 2006;24(4):685-94. Portuguese. Available from: https://doi.org/10.1590/S0100-83582006000400009

Sociedade Sul-Brasileira de Arroz Irrigado - Sosbai. [Irrigated rice: technical recommendations of the research for the South of Brazil]. Santa Maria: Sociedade Su-Brasileira de Arros Irrigado; 2014. Portuguese.

Tironi SP, Galon L, Concenco G, Ferreira EA, Silva AF, Aspiazu I, et al. [Competitive ability of rice plants with barnyardgrass biotypes resistant or susceptible to quinclorac]. Planta Daninha. 2009;27(2):257-63. Portuguese. Available from: https://doi.org/10.1590/S0100-83582009000200007 
Velini ED. [Interference between weeds and crops]. In: Kogan M, Lira VJE. [Avances en manejo de malezas en la produccion agricola y florestal]. Santiago do Chile: PUC/ALAM, 1992. p. 41-58. Spanish.

Yadav DB, Barebder S, SAnil D, Ashok Y, Punia SS. Penoxsulam + cyhalofop-butyl (premix) evaluation for control of complex weed flora in transplanted rice and its residual effects in rice-wheat cropping system. Ind J Weed Sci. 2018;50(4):333-9. Available from: https://doi.org/10.5958/0974-8164.2018.00072.2
Zhang W, Webster EP, Lanclos DY, Geaghan JP. Effect of weed interference duration and weed-free period on glufosinate-resistant rice (Oryzo sotivo). Weed Technol. 2003;17(4):876-80. Available from: https://doi.org/10.1614/wt-03-003r 